\title{
PREFACE to the Special Issue of Papers from the LFK Society YS Symposium
}

The primary goals of the Li Fang-Kuei Society (henceforth LFK Society) are to honor and preserve Professor Li Fang-Kuei's memory as a scholar and a man: to foster continuing research through the establishment of the journal Bulletin of Chinese Linguistics (henceforth BCL) in those academic areas to which he devoted his life, and to nurture future torch bearers in the spirit of innovation to continue this gentleman-scholar tradition through holding the Young Scholars Symposium (henceforth YS Symposium) periodically, as well as engaging in other related activities.

Professor Li Fang-Kuei was one of the greatest linguists of the twentieth century who was dedicated to excellence and integrity in scholarship. Throughout the course of his long and productive life, he not only strongly supported academic scholarship but also carefully attended to the upbringing of younger generations of scholars. The great achievement of Professor Li Fang-Kuei lies not just in his intellectual talent but also in the broadness of his academic training and interest, including field investigation of American Indian languages, Tai languages and Austronesian language (in Taiwan), historical comparative studies in Tai, historical study in Archaic Chinese, comparative study of classical Tibetan and Chinese, and Sino-Tibetan.

The purpose of the YS Symposium is to assemble a group of promising young scholars from all over the world who are working in academic areas related to those pursued by Professor Li Fang-Kuei during his scholarly life. Our hope is that the Symposium will facilitate free and open exchange of ideas in a stimulating and collegial environment of the sort that Professor Li Fang-Kuei himself always fostered and encouraged at scholarly gatherings. Although there are a sizeable number of bright young scholars in various sub-fields of Chinese and Sino-Tibetan linguistics, there are few opportunities for them to gather and share their ideas freely, to forge a sense of common identity and to formulate a vision for the future. The Symposium provides a platform for these promising young scholars to argue for their own viewpoints but at the same time to engage respectfully with differences of opinion, as well as to foster a spirit of cooperation, mutual support and productive criticism.

Through the Symposium we not only honor Prof. Li Fang-Kuei's rigorous scholarship and fine character, but also hope to instill these same qualities in the upcoming generation of scholars who will continue the outstanding legacy left to us by Professor Li Fang-Kuei.

In 2013, the LFK Society held its First three-day YS Symposium in Seattle, which was a resounding success. In 2018, the LFK Society held its Second three-day YS Symposium in Taiwan, which was another resounding success, resulting in the general demand of holding this Symposium regularly every five years.

The YS Symposium is unique in format in that the structure of the presentations lies in having each paper presented by a scholar other than the author and then discussed by an expert in the field, followed by a free and open general discussion. In addition, the young scholars share their academic interests through presenting research papers from different sub-disciplines using an innovative methodology of preparing and distributing their research papers several months before the Symposium and doing summaries of papers other than their own. The Symposium centers on discussion.

(C) KONINKLIJKE BRILL NV, LEIDEN, 2019 | DOI:10.1163/2405478X-01202006 
The present BCL volume bearing the theme of "Legacy and Innovation" contains contributions from young scholars who attended the Second YS Symposium. The special emphasis is on exploring new horizons in the disciplines of Sino-Tibetan linguistics in general and Chinese historical, comparative linguistics in particular. Fourteen promising young scholars were selected for participation from a pool of seventy-four young scholars recommended by the Board of Directors of the LFK Society and by worldrenowned senior scholars in historical and comparative studies. The selection criteria for qualified young scholar candidates include (1) must be under forty years of age in the year the symposium is held; (2) must hold a doctoral degree and have a current academic position at a university or research institution; (3) must have ability to use both Chinese and English for communication; (4) must show academic potential to develop into a promising scholar of the next generation of leaders in the fields of historical, comparative study of the Sinitic languages (including Sino-Xenic, i.e., Sino-Japanese, Sino-Korean, Sino-Vietnamese) in particular, Sino-Tibetan languages and Tai languages in general, as exemplified by the scholarship of Professor Li Fang-Kuei; (5) must be of gentlemanly and noble character, willing to engage with scholars in other disciplines, eager to explore and share new ideas, new methodologies, new perspectives and new disciplines through creative interactions, thereby broadening their minds and widening their horizons.

\section{THE YOUNG SCHOLAR PAPERS}

In the order of their appearance in BCL 12.1, the YS papers include:

\begin{tabular}{|l|l|}
\hline *李王癸 & 李方桂先生調查西南少數民族語言的足跡 \\
\hline Guillaume Jacques & Fossil Nominalization Prefixes in Tibetan and Chinese \\
\hline 盛益民 & $\begin{array}{l}\text { 複數單數化與漢語方言單數代詞中後綴 }\ulcorner\text { 儂 }\lrcorner \text { 的來源-一- } \\
\text { 項語義創新及其對東南方言代詞系統的影響 }\end{array}$ \\
\hline 沈瑞清 & 黃坑話與早期閩北語 \\
\hline 野原將揮 (Nohara Masaki) & 構擬 “泉”字音一兼論 “同義換讀” \\
\hline 濱田武志 (Hamada Takeshi) & 論《蒙古字韻》所反映的漢語方言音系 \\
\hline
\end{tabular}

*This article is not by a YS but an invited speaker at the Symposium.

while BCL 12.2 includes the following YS papers:

\begin{tabular}{|c|c|}
\hline 杜佳倫 & 論 $「$ 把/曳」與 $「$ 掣」的源流關係及其在閩語的發展演變 \\
\hline Nathan Hill \& Mattis List & $\begin{array}{l}\text { Directed networks as a technique for exploring features of the Old Chinese } \\
\text { Phonology } \\
\text { reflected in phonophoric patterns of character derivation }\end{array}$ \\
\hline 李子鶴 & 原始納西語詞首輔音叢的來源與演變 \\
\hline Nathan Hill & The prefix g-and -o- ablaut in Tibetan present verb stems \\
\hline 申祐先 & $\begin{array}{l}\text { 論韓國漢字詞 }\ulcorner\text { 반지 pan.tsi }\lrcorner 、\ulcorner\text { 겨자 kje.tsa }\lrcorner 、\ulcorner\text { 우두 u.tu }\lrcorner 、\ulcorner\text { 선비 } \\
\text { sen.pi }\lrcorner 、\ulcorner\text { 매 mai }\lrcorner \text { 的本字 }\end{array}$ \\
\hline
\end{tabular}

Editors-in-Chief of BCL 


\section{「李方桂學會青年學者研討會」專輯 序}

李方桂學會（以下簡稱LFK學會）之宗旨，在仰懷李方桂先生其學其人。除刊行《中 國語言學集刊》（以下簡稱BCL）以紹續其畢生致力之學術研究外，並舉辦青年學者 研討會（以下簡稱YS研討會）及其他相關活動，以培育新秀，傳承其學術創新之精 神。

李方桂先生是二十世紀最偉大的語言學家之一，為學術的精進而奉獻心力。在長 期耕耘的一生之中，他不但大力促成了學術的進步，更念茲在茲地培育年輕世代的學 者。李先生的偉大成就，不僅來自天縱，更在其所學、所業之深與廣，廣及美洲印地 安語、台語、台灣南島語之調查，漢語上古音之歷史研究，以及古典藏語與漢語、漢 藏語的比較研究等等。

舉辦YS研討會的目的，是要集結世界各地學術領域與李先生相同的優秀青年學者 於一堂。如李先生於學術聚會中經常倡導的, 我們期望這項研討會能在相互激盪和共 同討論的環境之中進行。雖然在漢語、漢藏語的各領域都有不少出色的年輕學者, 但 是讓他們聚在一起自由的發抒已見、凝鑄共識、規劃遠景，這樣的機會卻很少。因此 我們希望這個研討會能為新秀提供平台，讓他們盡情闠述自己的主張，認真考慮不同 的見解，並培養友直、友諒、友多聞的精神。

藉由研討會的活動, 我們不但向李先生嚴謹的治學和完美的人格致敬, 也要將這 些特質傾注於年輕的一代，讓他們傳承李先生超群的典範。

LFK學會在 2013 年曾於西雅圖舉辦過為期三天的第一屆YS研討會，得到極大的回 響。2018年，LFK學會在台灣舉辦了同樣是三天的第二屆研討會，得到了又一次的成功 回響，並獲得學界的普遍支持，期待每隔五年舉辦一次同樣的研討會。

YS研討會的進行方式殊為獨特。每篇論文先由作者本人以外的學者宣讀, 其次由 同領域的專家講評，然後進行公開討論。研討會的設計，以討論為主。作者需在會前 數月即將論文備妥分致各人，而在收到他人論文之後，必須預撰閱讀摘要。由於研討 會獨特的討論方式, 因此與會青年學者的次領域雖然不同, 卻能通過論文互相交流, 共享所得。

本期的BCL主題為「傳承與創新」，乃第二屆研討會發表論文的選集，特別著重 探索一般漢藏語言學以及漢語歷史比較語言學各分支的新視角、新境界。青年學者的 選拔，第一輪由學會理事與國際知名歷史比較語言學資深專家共同推薦，共得七十四 位候選人。第二輪再從七十四位中選拔, 共有十四位脫穎而出參加研討會。選拔的準 則包括（一）研討會舉行之時，年在四十歲以下。（二）已獲博士學位，並任職於大 學或研究機構。（三）能以中英雙語溝通。（四）針對下列領域，有潛力成為新一代 的領軍人物：漢語歷史比較語言學各分支（含域外漢音，如漢日音、漢韓音、漢越 音）、一般漢藏語言學與台語; 這些都是李先生垂範後昆的領域。（五）人品足稱, 樂意博問群英、廣納新知、切磋环磨，以開拓心胸，通達其思。 


\section{青年學者論文}

茲依BCL十二卷一期目錄先後為序，略列青年學者論文如下：

\begin{tabular}{|l|l|}
\hline *李王癸 & 李方桂先生調查西南少數民族語言的足跡 \\
\hline Guillaume Jacques & Fossil Nominalization Prefixes in Tibetan and Chinese \\
\hline 盛益民 & $\begin{array}{l}\text { 複數單數化與漢語方言單數代詞中後緅「儂」的來源一- } \\
\text { 一項語義創新及其對東南方言代詞系統的影響 }\end{array}$ \\
\hline 沈瑞清 & 黃坑話與早期閩北語 \\
\hline 野原將揮 (Nohara Masaki) & 構擬 “泉”字音一兼論“同義換讀” \\
\hline 濱田武志 (Hamada Takeshi) & 論《蒙古字韻》所反映的漢語方言音系 \\
\hline
\end{tabular}

*本篇作者為特邀講員, 並非青年學者。

BCL十二卷二期則收錄下列各篇：

\begin{tabular}{|c|c|}
\hline 杜佳倫 & 論 $\ulcorner$ 抴/曳」與 $\ulcorner$ 掣」的源流關係及其在閩語的發展演變 \\
\hline Nathan Hill \& Mattis List & $\begin{array}{l}\text { Directed networks as a technique for exploring features of the Old Chinese } \\
\text { Phonology reflected in phonophoric patterns of character derivation }\end{array}$ \\
\hline 李子鶴 & 原始納西語詞首輔音叢的來源與演變 \\
\hline Nathan Hill & The prefix g- and -o- ablaut in Tibetan present verb stems \\
\hline 申祐先 & $\begin{array}{l}\text { 論韓國漢字詞 }\ulcorner\text { 반지 pan.tsi }\lrcorner 、\ulcorner\text { 겨자 kje.tsa }\lrcorner 、\ulcorner\text { 우두 u.tu }\lrcorner 、\ulcorner\text { 선 비 } \\
\text { sen.pi }\lrcorner 、\ulcorner\text { 매 mai }\lrcorner \text { 的本字 }\end{array}$ \\
\hline
\end{tabular}

BCL主編 